\title{
Determinação da Isolação Sonora de Fachadas em Andares Altos de Edificações
}

\author{
Rebeca Bayeh \\ Fúlvio Vittorino \\ Adriana Camargo de Brito \\ Marcelo de Mello Aquilino \\ Maria Akutsu \\ Cristina Yukari Kawakita Ikeda \\ Peter Joseph Barry
}

\section{Introdução}

O conforto acústico no interior dos recintos é um dos itens mais desejados pelos moradores de habitaçôes. Com o intuito de se conseguir uma sensação satisfatória de conforto para a grande maioria dos ocupantes de um ambiente, é necessário considerar vários parâmetros como: o nível de ruído médio; o tempo de reverberação; a ausência de fontes tonais; a garantia da privacidade; a ausência de grandes variaçôes temporais, como a causada pelo acionamento rápido de instalaçôes prediais, etc. De todos esses parâmetros, o nível médio de pressão sonora é o que, em geral, mais afeta essa sensação de conforto. Níveis adequados desse parâmetro são apresentados na norma NBR 10152 (ABNT, 1992).

Com enfoque voltado para a especificação de um desempenho mínimo dos diversos elementos de vedação de uma edificação, a norma NBR 15575 (ABNT, 2013) definiu valores limites para a isolação sonora desses elementos. Essas isolaçóes visam produzir atenuaçóes sonoras, tais que: a) resultem em níveis de ruído, no interior dos recintos, compatíveis com os especificados pela NBR 10152 (ABNT, 1992), em situaçóes típicas de ruído urbano; e b) 
garantam uma atenuação dos sons gerados no uso corriqueiro dos espaços vizinhos, de forma a garantir a privacidade dos ocupantes.

A isolação do ruído externo em habitações é condicionada pela composição dos elementos de vedação, pela sua forma de vinculação com os demais componentes da edificação e pela ausência de frestas e de outras falhas construtivas. Neste contexto, a norma NBR 15575-4 (ABNT, 2013) apresenta valores mínimos compulsórios de isolação sonora dos elementos de vedação a serem verificados em uma obra, levando em conta as condiçóes em que a edificação será entregue ao futuro proprietário.

Nessa norma da ABNT, são incluídos critérios e métodos para a verificação do isolamento ao ruído aéreo entre os meios externo e interno, caso de particular interesse no estudo de isolamento ao ruído em fachadas de edificações. São tratadas, também, a isolação sonora das vedaçôes entre unidades autônomas, como paredes divisórias de apartamentos vizinhos, e entre paredes em unidades autônomas voltadas para as áreas comuns, como churrasqueiras e salóes de festas.

Em outras partes da NBR 15575 (ABNT, 2013), são abordados, ademais, tanto o isolamento ao ruído aéreo transmitido por pisos e cobertura, como o de impacto em pisos, ambos com caráter normativo. Já a atenuaçáo do ruído causado por equipamento e instalaçôes prediais possui caráter informativo. Esses assuntos, entretanto, não serão tratados neste capítulo.

A seção 12.2.1.2 da norma em questão faz referência a um dos métodos de avaliação de isolação sonora presente na norma internacional ISO 140-5 (ISO, 1998), que foi substituída, em 2016, pela norma ISO 16283-3 (ISO, 2016). O procedimento citado diz respeito ao método global com uso de alto-falante, que exige a realização de medições com o sonômetro posicionado a uma distância de dois metros da fachada analisada, bem como a utilização de alto-falantes emitindo um ruído padronizado. Esse método é facilmente aplicável em ambientes situados no térreo ou até o primeiro pavimento da edificaçáo, contanto que haja uma área livre de obstáculos do lado externo, com espaço suficiente para que os alto-falantes e microfones sejam posicionados conforme as exigências da norma. Entretanto, para a sua utilização em fachadas de andares mais elevados, que se faz necessária em grandes centros urbanos, há várias dificuldades operacionais, até mesmo no que concerne à segurança dos profissionais que efetuam as mediçóes. 
O presente capítulo trata de alternativas para a avaliação da isolação sonora de fachadas à luz da nova norma NBR 15575-4 (ABNT, 2013), a fim de propor a incorporação de outro método de medição, previsto na norma ISO 16283-3 (ISO, 201). São apresentados os requisitos e exigências da norma, além de discussóes sobre a possibilidade de substituir os procedimentos de medição do nível de pressão sonora a uma distância de dois metros da fachada por uma mediçáo com os microfones e pré-amplificadores posicionados encostados à fachada; propondo ainda a substituição do conjunto "caixa acústica e gerador de sinal" como fonte de ruído pelo tráfego urbano.

\section{Normas NBR 15575-4 (ABNT, 2013) e ISO 16283-3 (ISO, 2016)}

A norma NBR 15575-4 (ABNT, 2013) prevê o uso de três métodos para verificação de desempenho acústico de elementos do sistema vertical de vedação externa:

- "Método de precisão realizado em laboratório: Este método determina a isolaçáo sonora de componentes e elementos construtivos (parede, janela, porta e outros), fornecendo valores de referência de cálculo para projetos. $\mathrm{O}$ método de ensaio é descrito na ISO 10140-2. Para avaliar um projeto com diversos elementos (parede com janela, parede com porta, etc.), é necessário ensaiar cada um e depois calcular o isolamento global do conjunto";

- "Método de engenharia realizado em campo para fachadas: determina, em campo, de forma rigorosa, o isolamento sonoro global da vedação externa sob avaliação (conjunto fachada e cobertura, no caso de casas térreas e sobrados e somente fachada nos edifícios multipiso), caracterizando de forma direta o comportamento acústico do sistema. O método é descrito na ISO 140-5" (Substituída no ano de 2016 pela Norma ISO 16283-3). O método de engenharia com caráter normativo é usado para avaliação de desempenho da edificação a ser entregue para o comprador. Esse método determina de forma rigorosa (via medição) o tempo de reverberação no ambiente de recepção. $\mathrm{O}$ resultado obtido caracteriza de forma direta o comportamento acústico do elemento construído. Assim, o resultado se restringe somente à situação avaliada;

- "Método simplificado de campo: Este método permite obter uma estimativa do isolamento sonoro global da vedação externa (...) em situaçôes onde não se dispóe de instrumentação necessária para medir o tempo de reverberação, ou quando as condiçóes de ruído de fundo não permitem obter este parâmetro. O método simplificado é descrito na ISO 10052". O método simplificado 
também tem caráter normativo para avaliação de desempenho da edificação a ser entregue para o comprador. O método simplificado estima (via cálculo) o tempo de reverberação no ambiente de recepção.

Os métodos de campo adotam o parâmetro $\mathrm{D}_{2 \mathrm{~m}, \mathrm{nT}, \mathrm{w}}$ (diferença padronizada de nível ponderada a dois metros de distância da fachada) para determinaçáo do isolamento sonoro global de vedaçóes externas e abrangem unicamente o método global com uso de alto-falantes (descrito no item 9 da norma ISO 16283-3 (ISO, 2016).

O cálculo da ponderação $(w)$ é descrito na norma ISO 717-1 (ISO, 2013), enquanto o cálculo da diferença de nível sonoro normalizada, definido na norma ISO 16283-3 (ISO, 2016), é dado pela Equação 1, em que: $D_{2 \mathrm{~m}}$ é a diferença de nível de pressão sonora entre o valor medido no interior da unidade $\left(L_{\mathrm{R}}\right)$ e o valor medido a dois metros da fachada $\left(L_{\mathrm{E}}\right)$, em dB; $T$ é o tempo de reverberação no interior da unidade; e $T_{0}$ é o tempo de reverberaçáo padronizado como 0,5 segundo.

$$
\mathrm{D}_{2 \mathrm{~m}, \mathrm{nT}}=\mathrm{D}_{2 \mathrm{~m}}+10 \log \left(\mathrm{T} / \mathrm{T}_{0}\right)
$$

Na Figura 1, é apresentado um esquema que indica as mediçóes de nível de pressão sonora utilizadas para o cálculo da diferença de nível de pressão sonora. Na Figura 2, é apresentada uma foto ilustrando um ensaio de fachada realizado em uma habitação térrea, com posicionamento de microfone e de alto-falante conforme o método global com uso de altofalante, definido na ISO 16283-3 (ISO, 2016).

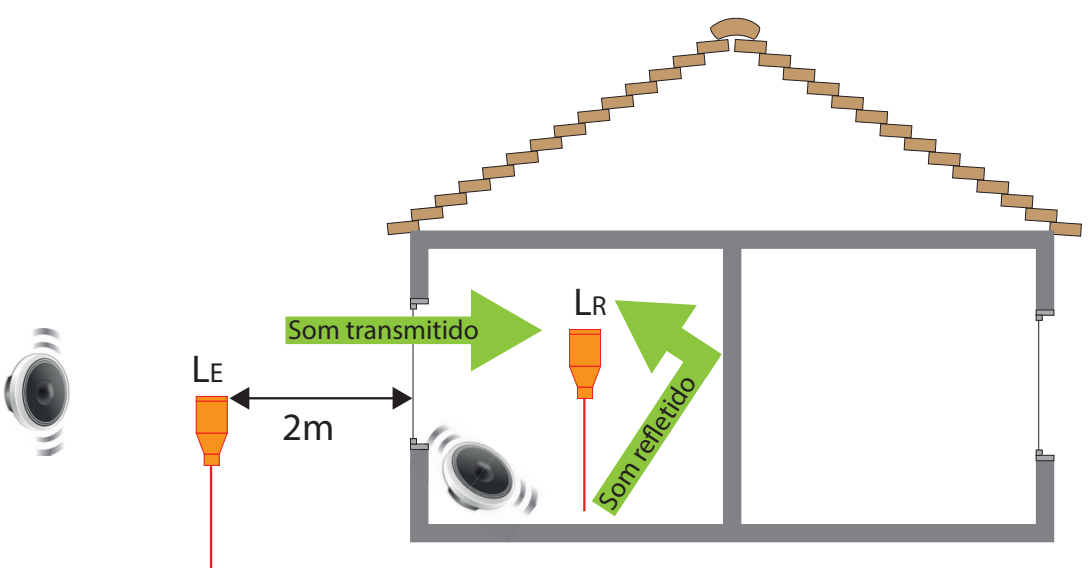

Figura 1. Esquema de medições externas e internas à unidade avaliada. 


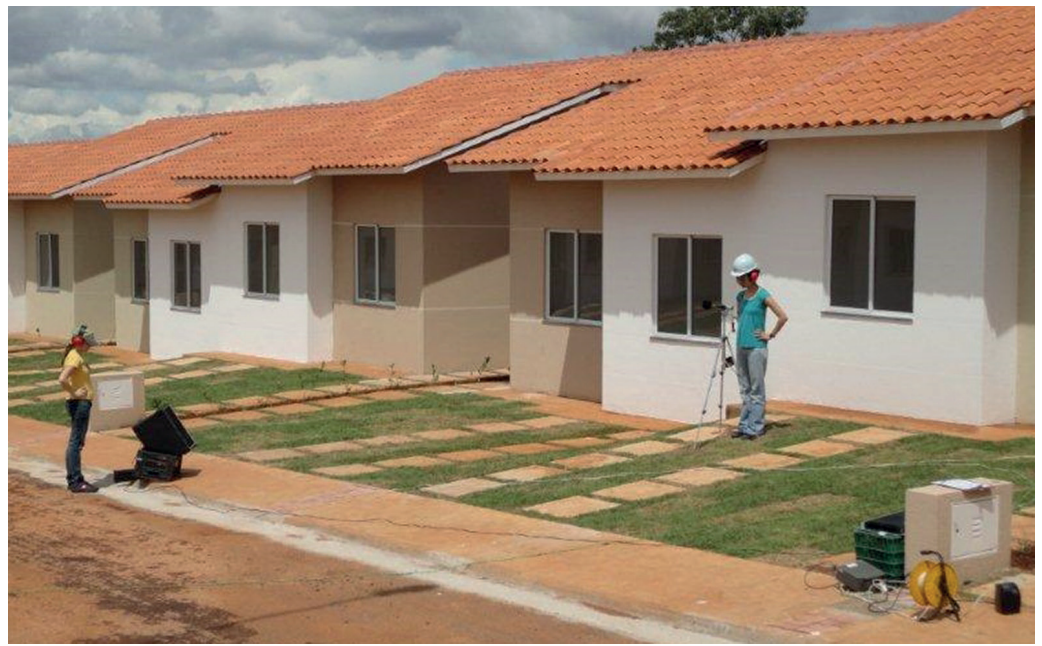

Figura 2. Preparação para realização de ensaio em habitação térrea.

A Tabela 1, reproduzida de acordo com o anexo F da NBR 15575 (ABNT, 2013), indica o nível de desempenho das vedações externas em função da condição de exposição da habitação. Observa-se que, entre um nível de classificação de desempenho e outro, a diferença de valores medidos para o $\mathrm{D}_{2 \mathrm{~m}, \mathrm{n} \text { T,w }}$ é de $5 \mathrm{~dB}$. Os procedimentos testados no presente trabalho visam obter variaçóes em relação às medições feitas com o microfone $2 \mathrm{~m}$ distante da fachada, as quais se mostram muito menores do que esse valor.

Tabela 1. Desempenho acústico da fachada em função da diferença padronizada de nível ponderada da $\left(D_{2 m, n T, w}\right)$ para ensaios de campo, classificado como $M$ (mínimo, normativo), I (intermediário, informativo) ou $\mathrm{S}$ (superior, informativo). (Transcrito da NBR 15575).

\begin{tabular}{|c|c|c|c|}
\hline $\begin{array}{l}\text { Classe de } \\
\text { Ruído }\end{array}$ & Localização da Habitação & $D_{2 m, n T, w}(d B)$ & $\begin{array}{c}\text { Nível de } \\
\text { Desempenho }\end{array}$ \\
\hline \multirow{3}{*}{ I } & \multirow{3}{*}{$\begin{array}{l}\text { Habitação localizada distante de fontes de } \\
\text { ruído intenso de quaisquer naturezas }\end{array}$} & $\geq 20$ & $\mathrm{M}$ \\
\hline & & $\geq 25$ & I \\
\hline & & $\geq 30$ & $\mathrm{~S}$ \\
\hline \multirow{3}{*}{ II } & \multirow{3}{*}{$\begin{array}{c}\text { Habitação localizada em áreas sujeitas a } \\
\text { situações de ruído não enquadráveis nas } \\
\text { classes I e III }\end{array}$} & $\geq 25$ & $\mathrm{M}$ \\
\hline & & $\geq 30$ & I \\
\hline & & $\geq 35$ & $S$ \\
\hline \multirow{3}{*}{ III } & \multirow{3}{*}{$\begin{array}{l}\text { Habitação sujeita a ruído intenso de meios } \\
\text { de transporte e de outras naturezas, desde } \\
\text { que esteja de acordo com legislação }\end{array}$} & $\geq 30$ & M \\
\hline & & $\geq 35$ & 1 \\
\hline & & $\geq 40$ & $\mathrm{~S}$ \\
\hline
\end{tabular}


Entretanto, os itens 9 e 10 da norma ISO 16283-3 (ISO, 2016) descrevem um total de quatro métodos:

- Método global com uso de alto-falante;

- Método de elemento com uso de alto-falante;

- Método global com uso de ruído de tráfego;

- Método de elemento com uso de ruído de tráfego.

Na norma ISO 16283-3 (ISO, 2016), especifica-se que a distância mínima (Dmin) entre o alto-falante e o centro do corpo de prova deve ser de 5,0 m para o método de elemento e de 7,0 m para o método global. $\mathrm{O}$ instrumento tem, além disso, que se localizar à maior distância possível do solo. A caixa acústica deve estar posicionada de forma que uma linha entre o seu centro e o centro do corpo de prova forme um ângulo de $45^{\circ} \pm 5^{\circ}$ em relação a um plano vertical que atravessa o centro da fachada. $\mathrm{O}$ microfone, durante as mediçôes externas, precisa estar a uma altura de $1,5 \mathrm{~m}$ em relação ao piso da unidade avaliada. Na Figura 3, é indicado um dos dois posicionamentos possíveis para a caixa acústica, com relação à fachada, para ensaios de campo, utilizando o método global a partir do uso de alto-falantes, de forma a atender às exigências normatizadas de distância e ângulo. $\mathrm{O}$ outro posicionamento é simétrico ao indicado, em relação ao plano perpendicular à fachada.

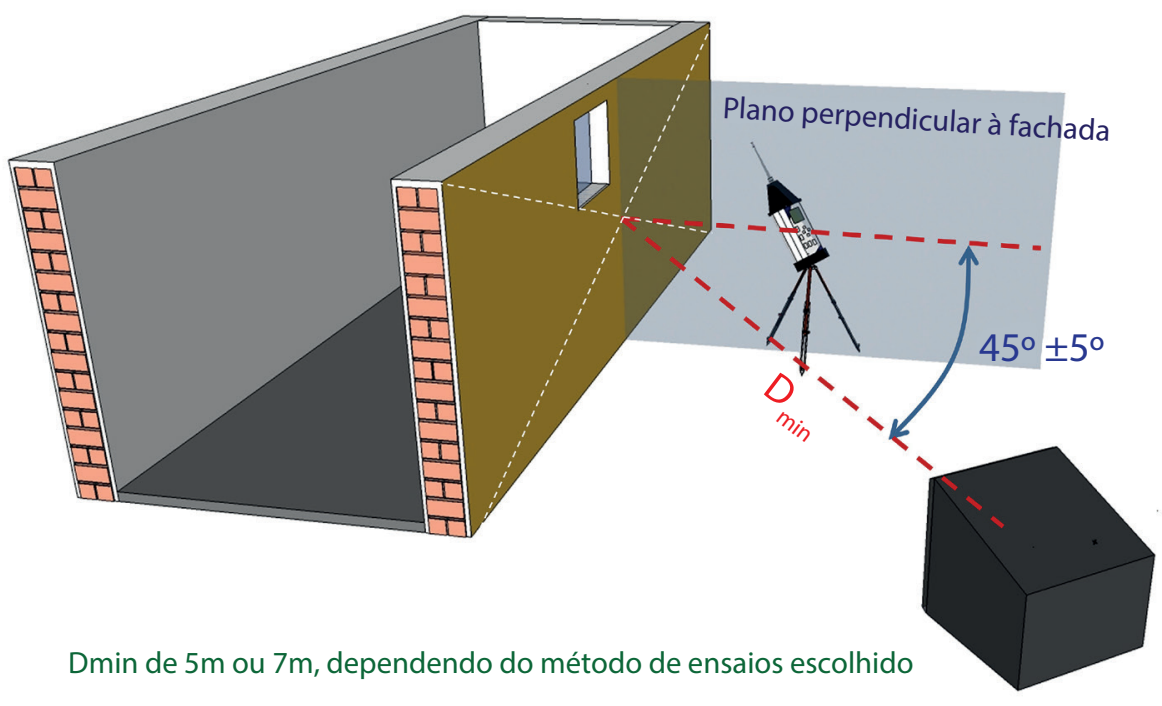

Figura 3. Ilustração esquemática dos pontos de posicionamento da caixa acústica $(\mathrm{A}$ e B). 
Para mediçóes em andares elevados, além da dificuldade de se erguer toda a instrumentação, a realização do ensaio implica em risco a quem executa o trabalho e em possibilidade de dano aos equipamentos, tendo em vista a altura em relação ao solo e a presença de vento, que pode causar a movimentação de todo o sistema de mediçôes, desestabilizando-o.

As Figuras 4 a 6 ilustram aspectos operacionais do uso do método descrito para ensaio em campo em um andar ligeiramente mais elevado de uma edificação, onde ainda foi possível utilizar-se de andaimes para apoio de toda a instrumentação.

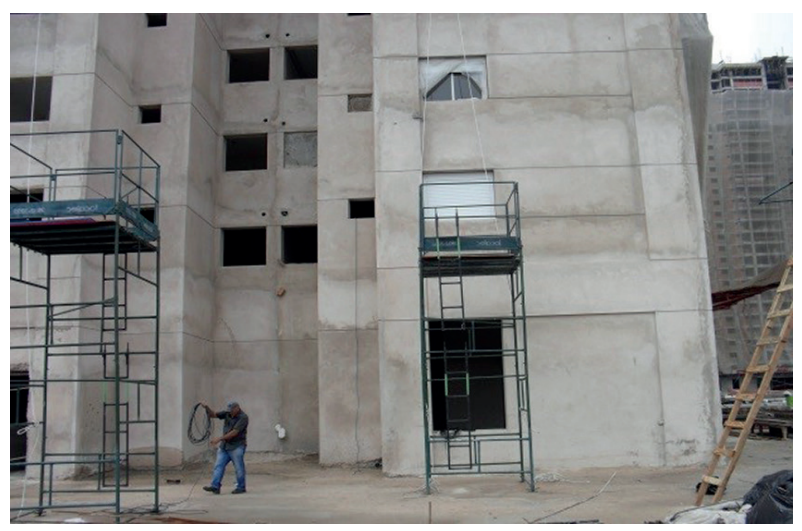

Figura 4. Andaimes utilizados para apoio da caixa acústica e do medidor de nível sonoro, a fim de se realizar ensaio em fachda situada no $1^{\circ}$ andar de edifício.
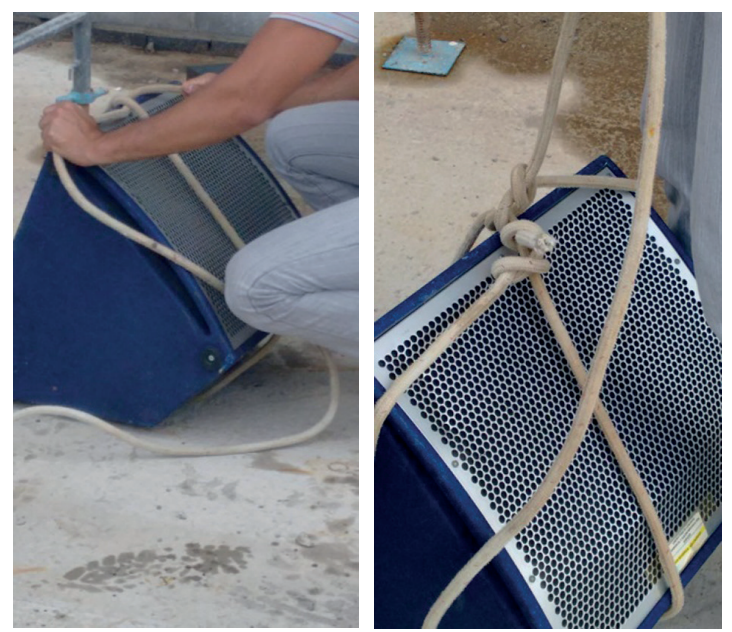

Figura 5. Uso de cordas para elevação da caixa acústica à altura do piso da unidade avaliada. 

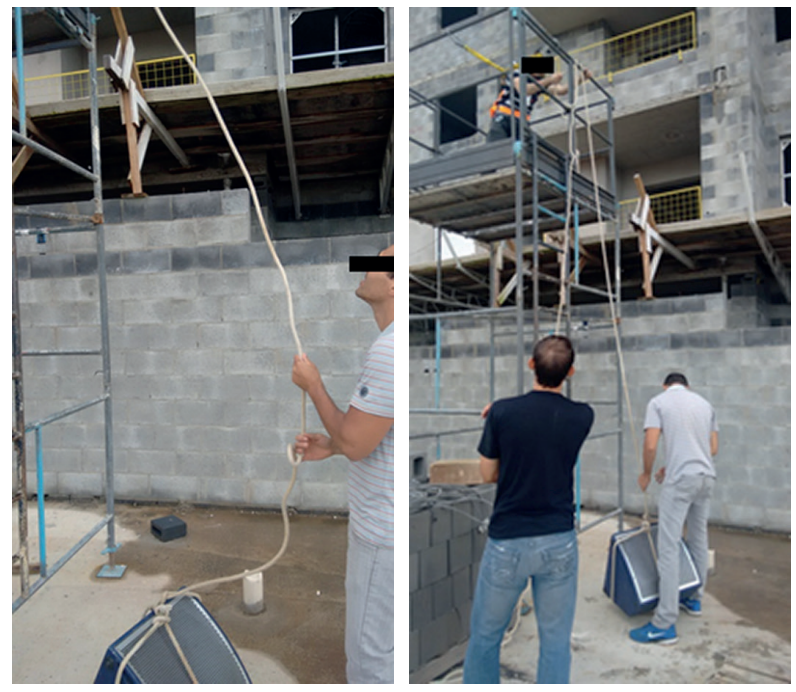

Figura 6. Elevação de caixa acústica para realização de ensaio.

As especificidades de cada um dos quatro métodos descritos na norma ISO 16283-3 (ISO, 2016) são apresentadas a seguir.

\subsection{Método Global com Uso de Alto-Falante}

O método global com uso de alto-falantes foi detalhadamente apresentado anteriormente e visa medir a isolação sonora de toda a fachada. Apesar disso, vale acrescentar alguns detalhes: admite-se uma incerteza de $\pm 0,2 \mathrm{~m}$ em relação à posição especificada de 2,0 $\mathrm{m}$ do plano da fachada; o microfone deve estar posicionado a 1,0 $\mathrm{m}$ dos guarda-corpos ou outros elementos protuberantes. No caso do uso de mais de uma posição de altofalante, a diferença média no nível de pressão sonora $\left(\mathrm{D}_{1 \mathrm{~s}, 2 \mathrm{~m}}\right)$ é dada pela Equação 2, também reproduzida da norma, em que $n$ é o número de posições utilizadas e $D i$ é a diferença de nível para cada medição realizada.

$$
\mathrm{D}_{\mathrm{ls}, 2 \mathrm{~m}}=-10 \lg \left(\frac{1}{\mathrm{n}} \sum_{\mathrm{i}=1}^{\mathrm{n}} 10^{-\mathrm{D}_{\mathrm{i}} / 10}\right)
$$

\subsection{Método de Elemento com uso de Alto-falante}

O método de elemento visa determinar a isolação sonora de um elemento da fachada, como uma janela, e recomenda o uso do microfone 
rente ao componente a ser ensaiado. O princípio pode ser aplicado a toda a fachada a ser testada. A norma ISO determina que o instrumento seja fixado juntamente com o pré-amplificador, de forma estável, para evitar alteraçôes em seu posicionamento, utilizando ainda espuma protetora contra o vento em formato hemisférico, como indicado na Figura 7, reproduzida conforme consta na norma ISO. A distância do eixo do microfone em relação à fachada deve ser de no máximo $3 \mathrm{~mm}$, caso seja paralelo à esse local. Caso seja perpendicular, a distância da membrana do microfone até a fachada deve ser de no máximo $10 \mathrm{~mm}$. Cabos e equipamentos náo podem interferir na transmissão do som à fachada testada.

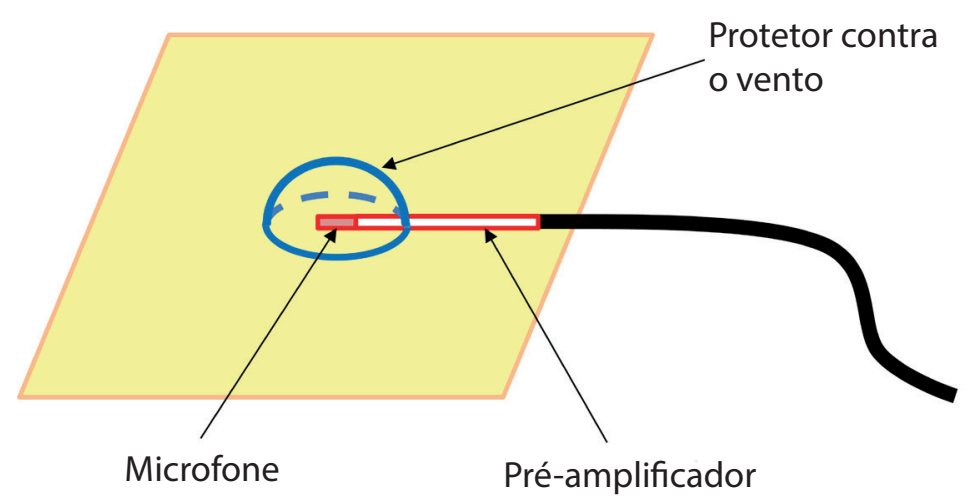

Figura 7. Esquema para microfone embutido com eixo paralelo à fachada e protetor hemisférico contra o vento (ISO, 2016).

Devem ser utilizados entre três e dez pontos de mediçáo para o microfone, distribuídos de forma assimétrica sobre a superfície. Recomendase iniciar com três pontos e verificar se a diferença dos níveis de pressão sonora medidos excedem os $3 \mathrm{~dB}$. Em caso afirmativo, escolher mais pontos até que o número de posiçôes exceda o número de decibéis, atingindo uma diferença, entre quaisquer duas mediçóes de nível de pressão sonora, de até no máximo dez pontos (se a diferença ultrapassar os $10 \mathrm{~dB}$, deve-se informar no relatório o valor verificado). Em caso de mediçóes em recessos de fachada, devem ser realizadas medições em dez pontos.

A fórmula utilizada para calcular o nível de pressão sonora externo médio $\left(L_{1, \mathrm{~s}}\right)$ na superfície de teste a partir de $n$ mediçóes $\left(L_{\mathrm{i}}\right)$ é dada pela Equação 3, também reproduzida a partir da seção 9 da norma ISO 16283-3. 


$$
\mathrm{L}_{1, \mathrm{~s}}=10 \lg \left(\frac{1}{\mathrm{n}} \sum_{\mathrm{i}=1}^{\mathrm{n}} 10^{\mathrm{L}_{\mathrm{i}} / 10}\right)
$$

O método de elemento prescrito na norma considera o uso de modelos de microfones e pré-amplificadores comumente encontrados em sonômetros, sem se atentar para outros tipos de microfones de menores dimensóes, construídos, especificamente, para serem montados em superfícies (Figura 8), talvez pela maior robustez dos primeiros em relação aos do segundo modelo. Nesse sentido, todo o trabalho foi conduzido com os microfones e pré-amplificadores de uso mais frequente.

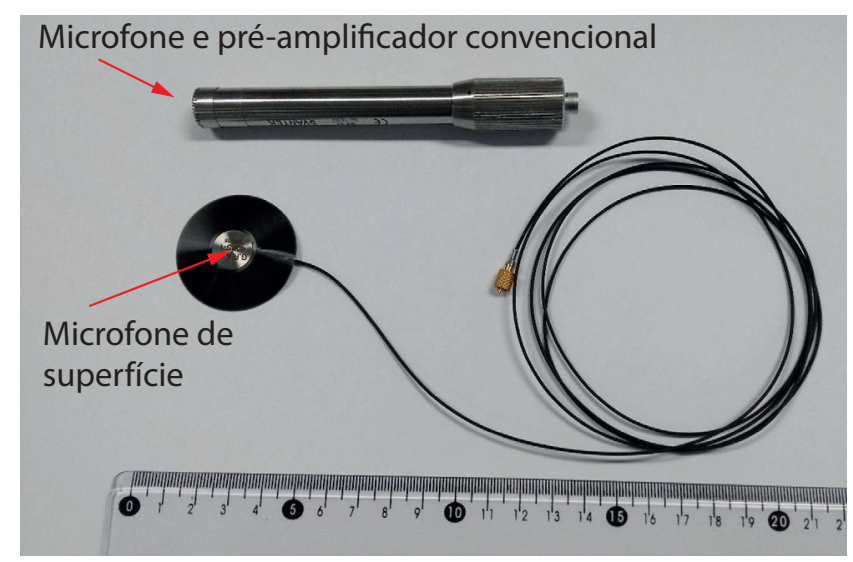

Figura 8. Comparação entre o microfone de fachada e microfone e préamplificador usado em sonômetros convencionais.

Ressalta-se que o uso de alto-falantes, tanto para o método global quanto para o de elemento, também deve atender a requisitos para a geraçáo do campo sonoro. Podem ser utilizados ruídos rosa ou branco, e, para cada banda de terço de oitava, por exemplo, o nível de pressão sonora não deve variar mais que $4 \mathrm{~dB}$ para bandas com centro em $250 \mathrm{~Hz}$ ou mais. O campo sonoro gerado deve ser estável, e o nível de pressão sonora recebido na unidade avaliada deve exceder o ruído de fundo em no mínimo $6 \mathrm{~dB}$.

\subsection{Método de Elemento com Uso de Ruído de Tráfego}

Os métodos que utilizam ruído de tráfego, descritos na seção $10 \mathrm{da}$ norma ISO 16283-3 (ISO, 2016), são indicados para casos em que o uso 
dos métodos que utilizam alto-falantes não podem ser efetuados por razóes práticas, o que deve ser também reportado nos relatórios ou quando se deseja realizar comparaçóes com resultados obtidos em laboratório.

No que se refere ao método de elementos, indica-se que, para cada medição, deve haver a presença de, pelo menos, cinquenta veículos em movimento, em um período de tempo mínimo de quinze segundos. Esta exigência visa produzir uma fonte sonora estável e condiciona os melhores horários de medição, visto que nos horários de pico de cidades grandes o fluxo de veículos pode ser mais lento. O fluxo do tráfego deve seguir uma trajetória aproximadamente linear dentro de um ângulo inferior a $60^{\circ} \mathrm{em}$ relação à fachada, com desvios permitidos de $15^{\circ}$.

Além disso, o ângulo de elevação entre a fachada estudada e a linha de tráfego deve ser inferior a $40^{\circ}$, medida que possibilita observar a fachada inteira em toda a linha de tráfego utilizada. A distância entre esta linha e a fachada deve ser ou de $25 \mathrm{~m}$ ou três vezes a largura da fachada, optando-se por aquela que for maior.

As demais condiçôes de medição são equivalentes às do método de elemento com uso de alto-falante, utilizando o microfone rente à fachada. $\mathrm{O}$ cálculo de diferença de nível sonoro externo, que deve utilizar no mínimo três pontos de medição para fachadas planas ou cinco pontos para fachadas com recessos, é análogo ao do método global com uso de alto-falante, conforme Equação 3. O número de medições internas deve ser o mesmo de medições externas.

É importante ressaltar que o ruído de tráfego apresenta flutuaçóes no tempo. Portanto, para que ele possa ser utilizado em mediçóes de isolamento sonoro, as mediçốes dos níveis de ruído, interno e externo, devem ser realizadas simultaneamente. Para isso, pode-se recorrer ao uso de microfones acoplados a equipamento com dois canais ou ao uso de dois microfones em equipamentos independentes, desde que estes estejam devidamente sincronizados e configurados com mesmas taxas de aquisição de dados.

\subsection{Método Global com Uso de Ruído de Tráfego}

O método global com uso de ruído de tráfego exige condiçóes geométricas similares às do método global com uso de alto-falante. Demanda também requisitos iguais aos exigidos no método de elemento com uso de ruído de tráfego para uso do ruído de tráfego como fonte sonora. 
O microfone deve estar a $1,5 \mathrm{~m}$ de altura em relação ao piso do cômodo analisado, e o cálculo de nível de pressão sonora médio é também análogo ao descrito na Equação 3.

\section{Efeito da Reflexão do Ruído em Fachadas}

O ponto de partida para se determinar a isolação sonora da fachada de um edifício é a medição do ruído incidente sobre ela. A medição externa de ruídos para qualquer tipo de fonte sonora é condicionada à distância dos sonômetros utilizados com relação à fachada, visto que esta promove reflexão sonora, fator já bem documentado em literatura. A Figura 9 ilustra o som atingindo a superfície e mostra uma parcela dele sendo transmitida, outra parcela sendo absorvida pelo meio material e outra sendo refletida. Dessa maneira, é esperado que, ao realizar mediçóes junto à fachada, obtenha-se um nível de pressão sonora superior aos provenientes de mediçóes efetuadas em maior distância.

Em posiçôes rentes à fachada, a energia sonora é aproximadamente o dobro da energia incidente, devido à reflexão. Como o nível de pressão sonora é proporcional a dez vezes o logaritmo comum $\left(\log _{10}\right)$ da energia, dobrandose a energia, obtém-se um acréscimo de aproximadamente $3 \mathrm{~dB}$ no nível de pressão sonora. Hall et al. demonstraram que esta correção é satisfatória para bandas de terço de oitava centradas entre $200 \mathrm{~Hz}$ e $2000 \mathrm{~Hz}$ (HALL, 1984).

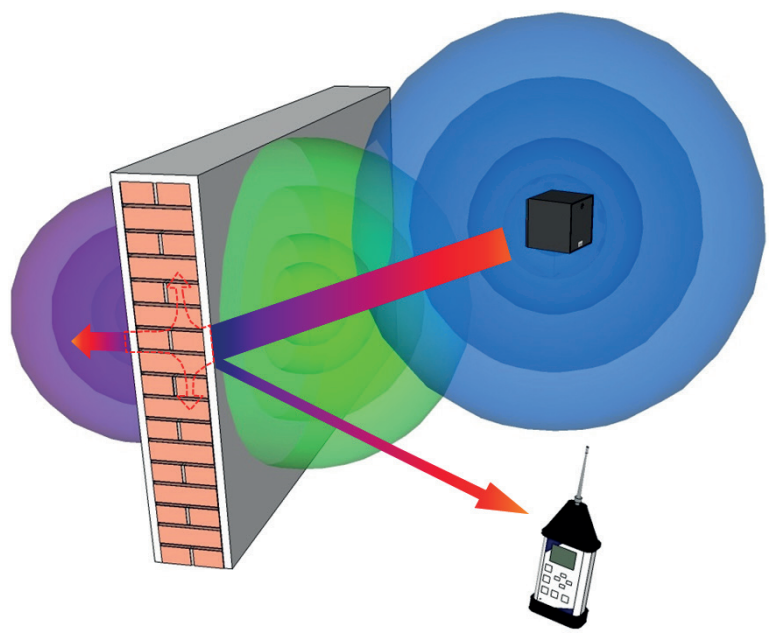

Figura 9. O ruído incidente sobre a fachada é parcialmente refletido, parcialmente absorvido e parcialmente transmitido. 
Contudo, a partir de medições de nível de pressão sonora próximas à fachada, realizadas pela equipe do Laboratório de Conforto Ambiental (LCAIPT, 2013) e de estudos realizados por autores como Sánchez Bote et al. (2012) e Berardi et al. (2012), tem-se verificado que a diferença de nível sonoro supracitada é inferior a $3 \mathrm{~dB}$, o que está relacionado com a absorção parcial do ruído pela fachada e com as diferenças de comportamento de difusão da reflexão das ondas sonoras em diferentes faixas de frequência, conforme detalhado mais adiante. Nesse sentido, a associação americana ASTM, no documento "Standard Guide for Field Measurements of Airborne Sound Insulation of Building Facades and Facade Elements" (ASTM E966, 2011 - itens 8.5.2 e 8.5.3), sugere a utilização de uma correção de $2 \mathrm{~dB}$ quando se utiliza o método de microfone próximo à fachada (caso em que a reflexão aumenta em aproximadamente duas vezes a pressão sonora incidente sobre o microfone) ou de $5 \mathrm{~dB}$ quando se utiliza o método de microfone embutido (caso em que a reflexão aumenta em aproximadamente quatro vezes a pressão sonora incidente sobre o microfone) no cálculo do índice de redução de ruído externo.

\section{Investigações com Uso dos Métodos}

Diversos estudos têm sido realizados com a finalidade de avaliar as incertezas nas mediçóes de grandezas associadas à inferência da isolação sonora em fachadas de edificaçôes, conforme as normas ISO 140-5 e sua substituta ISO 16283-3.

Idealmente, o melhor campo sonoro possível para evitar variaçóes do ruído diretamente incidente sobre as diferentes regióes da fachada é produzido por fontes omnidirecionais. Sánchez Bote et al. demonstram que essa condição não é válida apenas para fachadas muito grandes, em que ocorrem muitas variaçôes locais de nível de pressão sonora total em cada ponto da fachada.

Foi demonstrado, pelos mesmos autores, que alto-falantes pequenos produzem campos próximos aos uniformes até a faixa de $5 \mathrm{kHz}$ (limite exigido nas normas ISO). Contudo, para estudo de baixas frequências são necessários alto-falantes com potência superior às encontradas, normalmente, em caixas muito pequenas. Também foi verificado que o uso de caixas dodecaédricas apresenta muita flutuação nas frequências próximas a $1 \mathrm{kHz}$, também não sendo recomendada sua utilização. 
Foi observado ademais o efeito da reflexão sonora da fachada e da absorção do solo em frente à fachada, sendo indicada a necessidade de qualificação dos alto-falantes em câmaras anecóicas antes de sua utilização em campo (SÁNCHEZ BOTE et al., 2012).

Beraldi aponta que, mesmo em condições experimentais próximas ao ideal, o uso de alto-falante provoca, inevitavelmente, interferências de onda nas regiôes próximas às fachadas, em especial em baixas frequências.

Nas bandas de terço de oitava com centro em $50 \mathrm{~Hz}$ e $63 \mathrm{~Hz}$, em diferentes pontos da fachada, é possível verificar diferenças de até $2 \mathrm{~dB}$, o que reforça a necessidade de se utilizar vários pontos de medição de nível de pressão sonora para reduzir o efeito da interferência destrutiva em baixas frequências. $\mathrm{O}$ autor também realizou medições de nível de pressão sonora a 1,0m da fachada, tendo concluído que interferências destrutivas ainda são evidentes nas bandas centradas em $63 \mathrm{~Hz}$ e $80 \mathrm{~Hz}$ (BERALDI, 2013).

Machimbarrena et al. (2015) demonstraram que nas bandas centradas em frequências médias e altas a incerteza intrínseca à instrumentação é superior para quaisquer tipos de fachadas.

Em fachadas construídas com materiais leves, contudo, as altas frequências apresentam níveis de pressão sonora com maior flutuação. O tempo de reverberação no interior da unidade estudada influi significantemente apenas em frequências inferiores a $500 \mathrm{~Hz}$ (MACHIBARRENA, 2015).

Com relação ao uso de ruído de tráfego, Olafsen aponta que os resultados obtidos utilizando o referido método em frequências entre $200 \mathrm{~Hz}$ e $1000 \mathrm{~Hz}$ são compatíveis àqueles obtidos utilizando-se alto-falantes. Abaixo de $200 \mathrm{~Hz}$, utilizar o ruído de tráfego resulta em valores de isolação sonora aparente inferiores, e acima de $1000 \mathrm{~Hz}$ o ruído de tráfego não apresenta energia suficiente para que seja avaliada a isolação sonora (OLAFSEN, 2012).

\section{Desenvolvimento de Método de Medição de Ruído em Fachadas}

Para se estudar a possibilidade de implantar métodos alternativos de medição e geração de ruído no exterior da edificação, foram feitas medições de nível de pressão sonora em várias situações, bastante distintas, a fim de se estimar: 
- A influência da distância do microfone às fachadas com rugosidades diferentes;

- A influência do uso do protetor contra o vento e do microfone junto à fachada.

Para se verificar a repetitividade dos equipamentos utilizados nas etapas anteriores, foram feitas repetiçóes, mudando-se o nível de pressão sonora emitida pelas caixas acústicas. Finalmente, foi feito um estudo exploratório sobre o uso do ruído de tráfego.

Todos os ensaios realizados com caixa acústica atenderam aos critérios da norma ISO 16283-3 (ISO, 2016). A caixa acústica foi posicionada em dois pontos diferentes para cada ensaio, ambos estabelecidos a 7,0 $\mathrm{m}$ de distância do centro da fachada e dispostos a um ângulo de $45^{\circ}$ com relação a esse local. Em todas as mediçóes, foram utilizados um sonômetro classe zero e uma caixa acústica direcional de $45^{\circ}$.

Nos ensaios realizados em fachadas de andares térreos, a altura do microfone com relação às fachadas foi mantida constante: a 1,5 m em relação ao solo. Nas mediçóes em que o tripé foi posicionado sobre a calçada, todas as extensóes desse suporte foram ajustadas para que altura fosse mantida constante com relação ao centro da fachada durante toda a série de mediçóes.

A caixa acústica emitiu ruído rosa em todos os ensaios e, tendo em vista o controle, para cada ensaio, foram realizadas mediçôes de calibração e de ruído de fundo.

\subsection{Influência da Distância do Microfone à Fachada}

Primeiramente, buscou-se avaliar a influência da posição do microfone em relação às fachadas abrangidas nas mediçóes de níveis de pressão sonora, levando em consideração a distância normalizada de 2,0 m. Em uma primeira série de ensaios, foram consideradas quatro fachadas construídas com diferentes materiais, ilustradas na Figura 10. As fachadas 1, 2, 3 e 4 pertencem respectivamente a edifícios com fachadas em: alvenaria revestida com pastilhas cerâmicas da ordem de $2 \mathrm{~cm}$ de lado; alvenaria de blocos de concreto aparentes; painéis de concreto recobertos com painéis metálicos; e cortinas de vidro - correspondentes aos blocos 31, 36, 50 (lateral) e 50 (posterior) do IPT.

Durante todas as medições, o sonômetro foi posicionado a 5,0 $\mathrm{m}$ de distância longitudinal da caixa (ora posicionada em A, ora em B, conforme Figura 11), sendo movido perpendicularmente com relaçáo à fachada durante 
as mediçôes. Quatro pontos de medição padrão foram utilizados, afastados de $0,5 \mathrm{~m}$ um do outro, representados também na Figura 11. As posições utilizadas distam $0,5 \mathrm{~m}, 1,0 \mathrm{~m}, 1,5 \mathrm{~m}$ e 2,0 $\mathrm{m}$ da fachada.
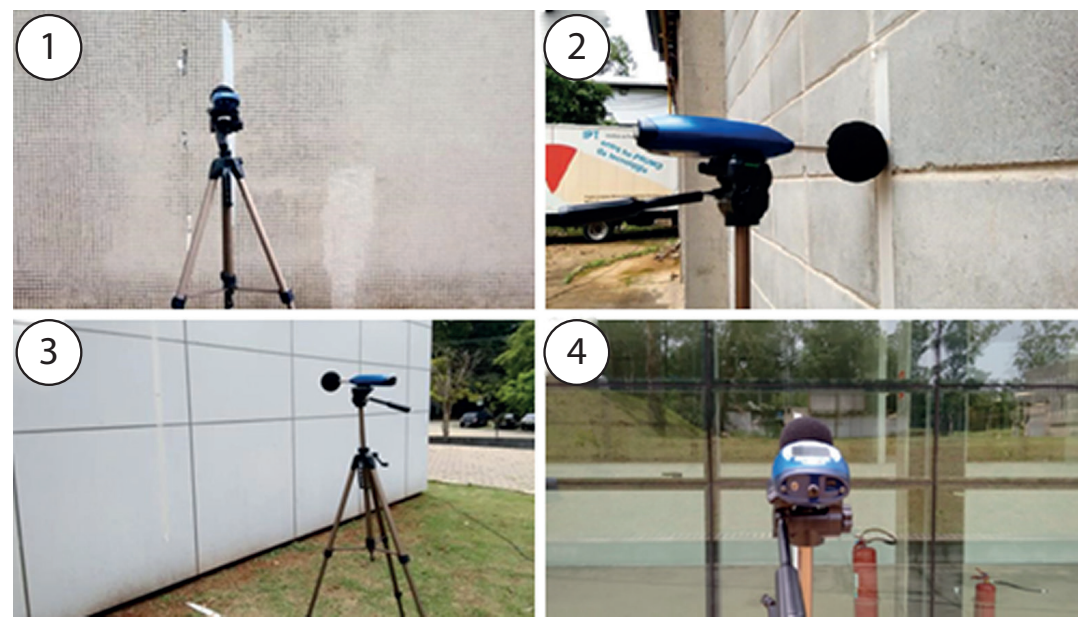

Figura 10. Fachadas utilizadas no estudo da influência da distância do microfone com relação à fachada.

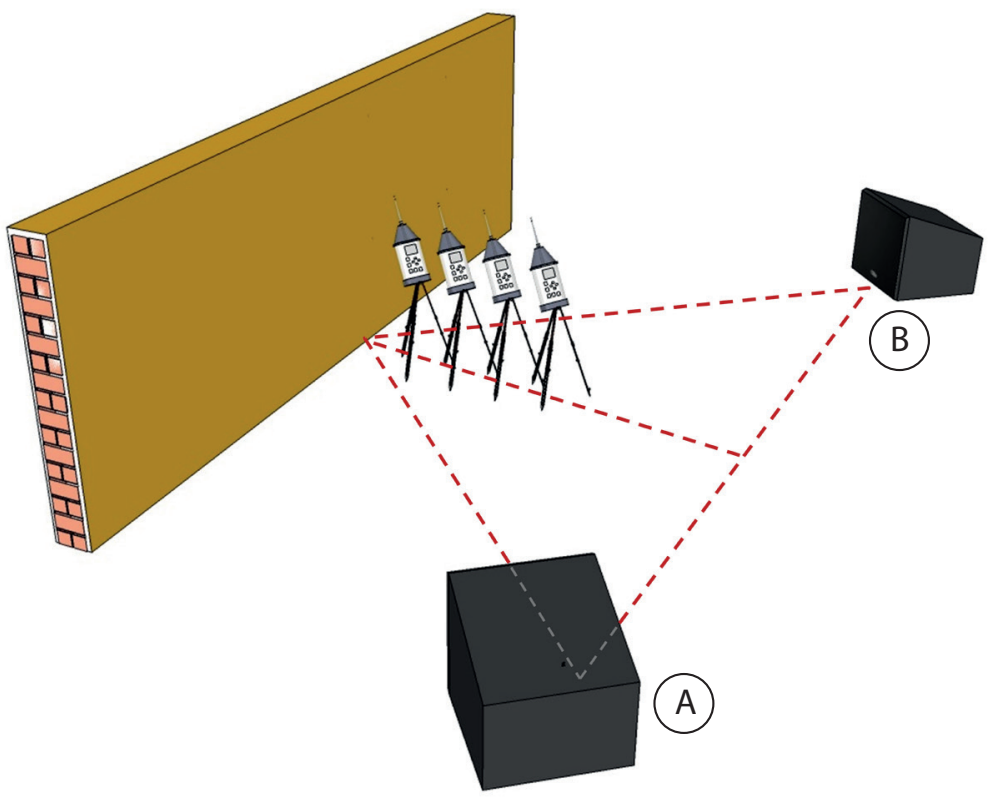

Figura 11. Posições utilizadas para fim de medição do nível de pressão sonora em frente à fachada. 
Na Figura 12, é apresentado o gráfico de nível de pressão sonora por fachada (1, 2, 3 e 4) e por posicionamento da caixa acústica (A e B).

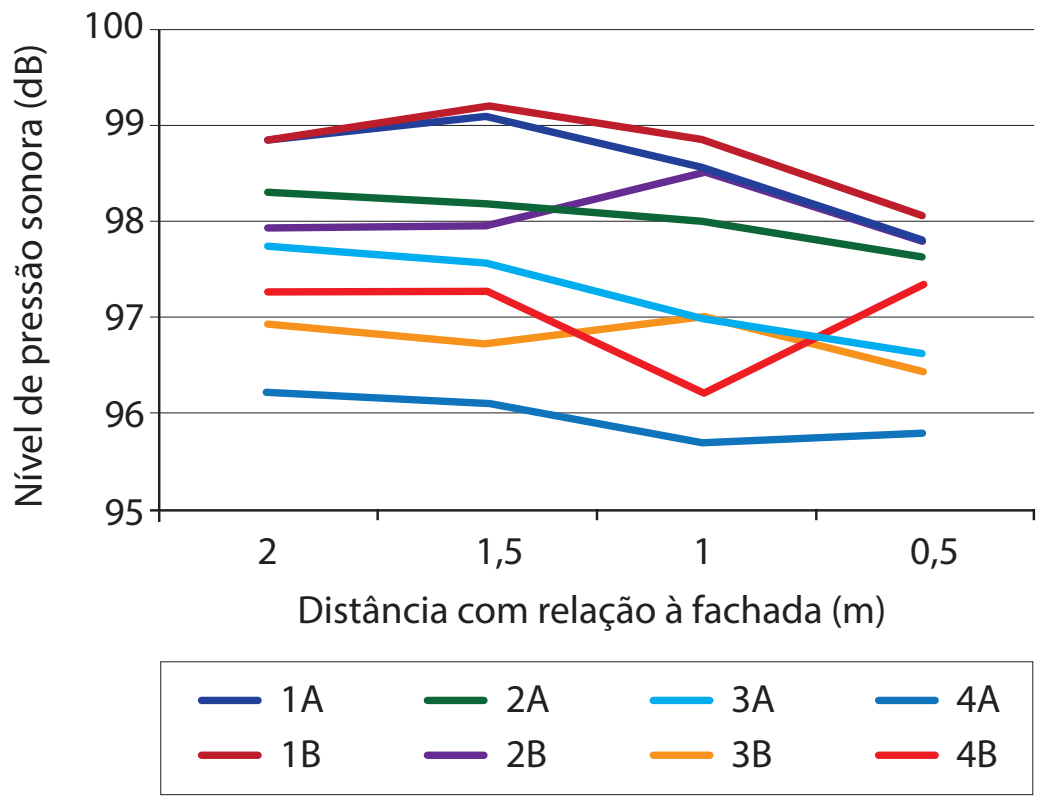

Figura 12. Influência da posição do ponto de medição e da fonte sonora no nível de pressão sonora.

Observa-se que o posicionamento da caixa influenciou em até $1,3 \mathrm{~dB}$ a diferença de nível de pressão sonora entre uma medição e outra (caso da fachada 3). Observa-se também que, nas fachadas 1 e 2 , houve aumento no nível de pressão sonora a $1,0 \mathrm{~m}$ ou $1,5 \mathrm{~m}$ de distância da fachada. Isto provavelmente ocorreu devido ao fato de ambas as fachadas estarem localizadas próximas a outras fachadas, o que pode ter provocado um efeito de paralelismo, a partir de reflexôes sucessivas do som, aumentando a pressão sonora nos pontos analisados.

Na Figura 13, está ilustrado o efeito de reflexôes sucessivas nos pontos intermediários de medição. 


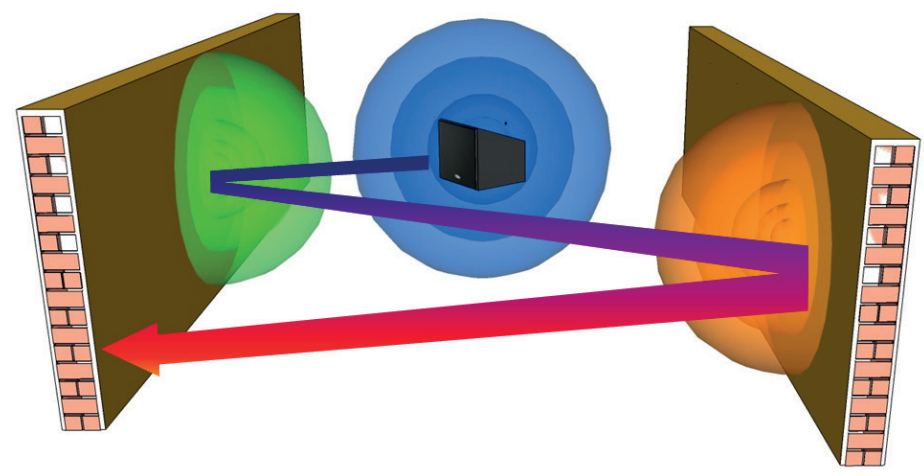

Figura 13. Paralelismo nas regiões intermediárias estudadas, devido às sucessivas reflexões

\subsection{A Influência do Uso do Protetor Contra o Vento e do Microfone Junto à Fachada}

Foram investigadas técnicas diferentes de posicionamento do microfone rente à fachada, a fim de se analisar a influência da reflexão da fachada sobre as mediçôes, bem como a viabilidade de procedimentos práticos de medição em campo.

O microfone foi fixado a, aproximadamente, 20 milímetros das quatro fachadas estudadas anteriormente, em duas condiçóes diferentes: apoiado sobre o tripé, com o protetor contra o vento (método I); e posicionando manualmente, sem espuma protetora (método II), conforme Figura 14.
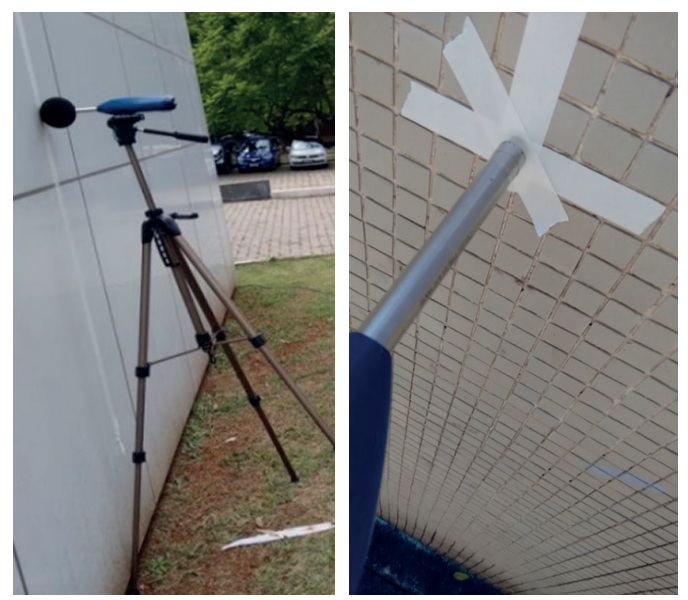

Figura 14. Métodos utilizados para medição de nível de pressão sonora nas fachadas. 
Na Figura 15, mostra-se uma comparação entre os dois métodos de medição rente à fachada com auxílio do gráfico de diferença de nível de pressão sonora entre dois metros da fachada e rente à esse mesmo local, utilizando-se ambos os métodos.

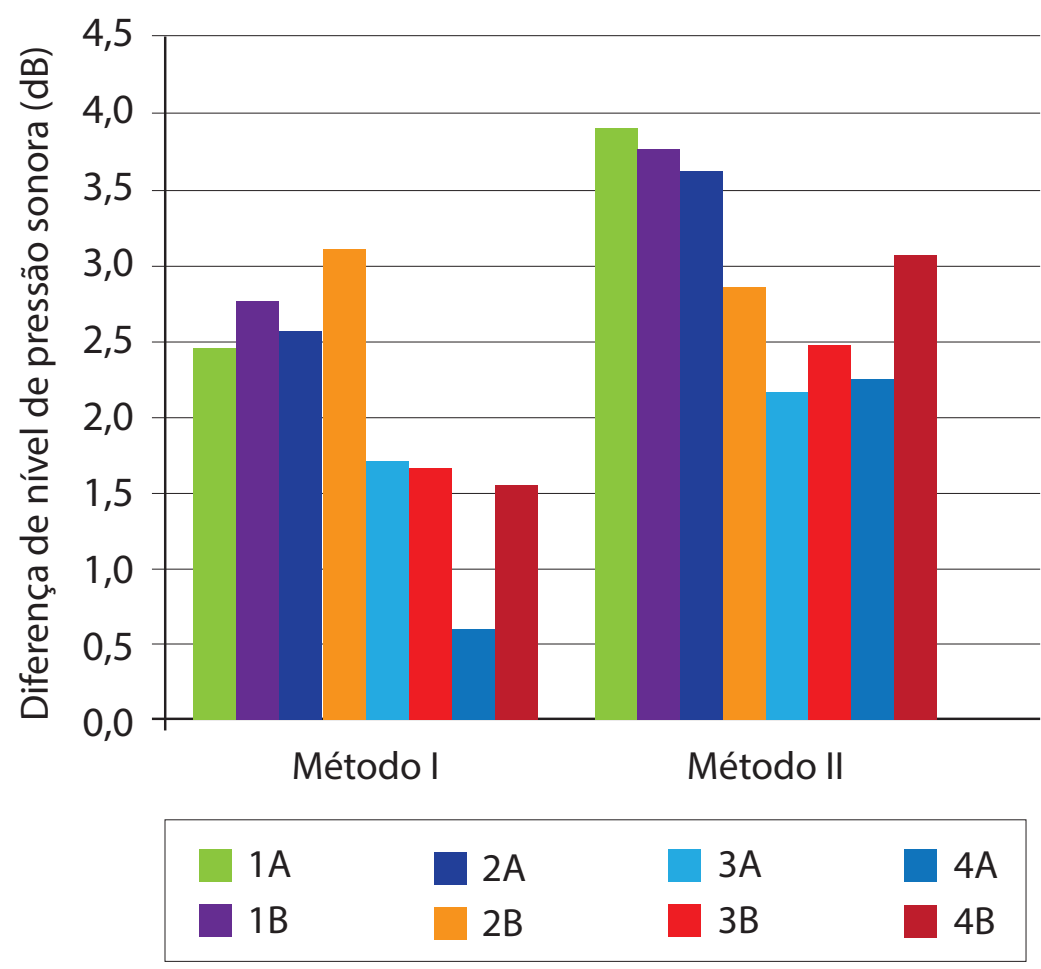

Figura 15. Comparação entre métodos de medições rentes à fachada.

Observa-se que, mesmo levando em conta as variáveis de rugosidade das fachadas, a posição das caixas, o uso da espuma protetora e a necessidade de se haver um operador sustentando manualmente o sonômetro, a maior flutuação obtida na diferença de nível de pressão sonora foi de 1,6 dB.

Observa-se também que o método II apresenta, em média, diferenças de nível de pressão sonora superiores às obtidas por meio do método I, o que sugere possível influência do operador enquanto corpo absorvedor. O método I pode ter reduzido, além disso, a distância da membrana do microfone com relação à fachada devido ao uso da espuma protetora. 


\subsection{Repetitividade dos Equipamentos Utilizados}

Para fim de verificaçáo da possibilidade de se obter repetitividade dos resultados anteriores, nas faixas de pressão sonora de interesse, foram escolhidos cinco níveis de pressão sonora para emissão de ruído rosa pela caixa acústica, entre 81,3 dB e 101,8 dB (medidos a dois metros da fachada), sendo controlados por intermédio do regulador de atenuaçóes ligado à caixa.

Medições de nível de pressão sonora rentes à fachada 1 foram realizadas novamente, nas mesmas condiçóes geométricas descritas nos estudos anteriores e com posicionamento de microfone conforme o método II. Na Figura 16, são indicadas as diferenças nos níveis de pressão sonora média, obtidas emitindo-se diferentes níveis de pressão sonora (i, ii, iii, iv e v) para cada posicionamento de caixa (A e B). A média das diferenças entre os pontos de medição foi de $3,5 \mathrm{~dB}$, e a maior flutuação obtida entre todas as médias de nível de pressão sonora foi $1,5 \mathrm{~dB}$.

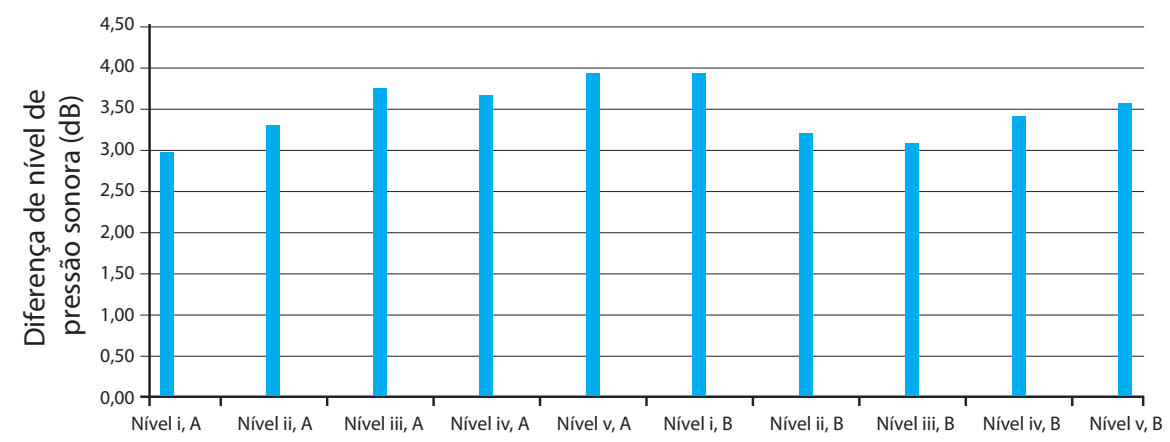

Figura 16. Diferença de nível de pressão sonora a dois metros da fachada e rente a esse mesmo local, emitindo-se cinco níveis de pressão sonora diferentes.

Observa-se que todos os níveis de pressão sonora utilizados forneceram valores compatíveis de diferença de nível de pressão sonora. Não são observadas diferenças significativas de comportamento da diferença de nível de pressão sonora entre os diferentes níveis totais emitidos.

Foi realizado, também, um ensaio de campo livre, a fim de se verificar a influência da posição da caixa na obtenção da diferença do nível de pressão sonora. Durante o ensaio, a caixa acústica e o microfone foram posicionados de forma a simular um ensaio como nos moldes descritos anteriormente, a menos da existência da fachada. Na Figura 17, são mostrados os níveis de pressão sonora medidos por banda de terço de oitava, utilizando duas 
posiçóes de caixa ( $\mathrm{A}$ e B) e duas posiçóes de microfones (a 5 metros e a 7 metros da fachada virtual). Na Figura 18, são indicadas as diferenças de nível de pressão sonora obtidos para ambas as posiçôes de caixa.

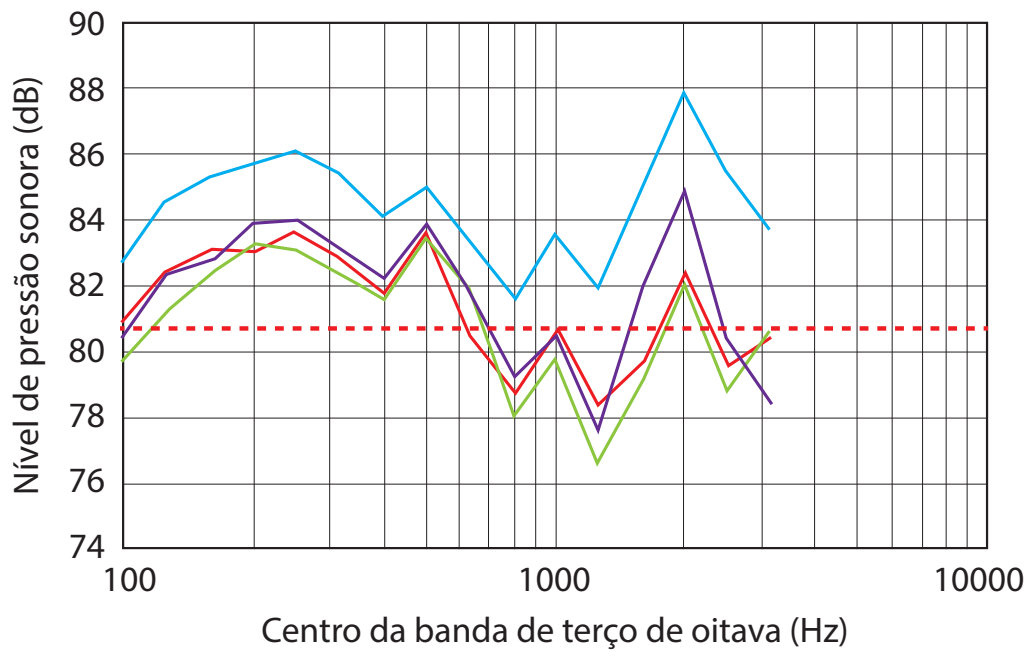

$-\mathrm{A}, 5 \mathrm{~m} \longrightarrow \mathrm{A}, 7 \mathrm{~m} \quad \mathrm{~B}, 7 \mathrm{~m} \quad \mathrm{~B}, 5 \mathrm{~m}$

Figura 17. Níveis de pressão sonora obtidos em ensaio de campo livre.

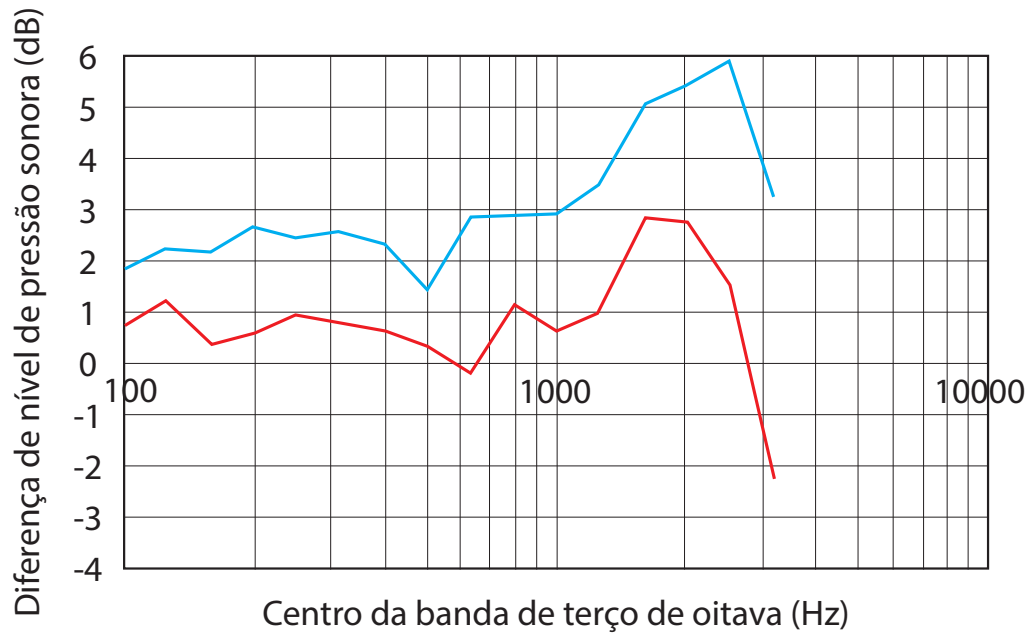

\section{Caixa em A Caixa em B}

Figura 18. Diferença de níveis de pressão sonora obtidos em ensaio de campo livre. 
As quatro mediçóes apresentaram coerência espectral tanto em termos de valor absoluto do nível de pressão sonora quanto em termos de diferença de nível sonoro a dois metros e rente à fachada virtual. Todas as diferenças de variação de nível de pressão sonora são inferiores a 3,1 dB entre as posições das caixas, exceto para as bandas de terço de oitava centradas em $2500 \mathrm{~Hz}$ e $3150 \mathrm{~Hz}$, discrepância esperada para altas frequências. A variação do nível de pressão sonora equivalente, que é a grandeza utilizada no cálculo do parâmetro $\mathrm{D}_{2 \mathrm{~m}}$, para as mediçóes a sete metros da caixa, lugar onde estaria localizada a fachada, foi de $0,4 \mathrm{~dB}$, valor que indica baixa influência da escolha do posicionamento da caixa em campo livre, desde que atendidos os requisitos geométricos utilizados.

\subsection{Exploração Sobre o Uso do Ruído de Tráfego}

Novos ensaios foram realizados, desta vez em duas fachadas do $1^{\circ}$ andar de um edifício em fase de obra, utilizando-se os mesmos equipamentos e posicionamentos de caixa que foram usados nos estudos anteriores.Foram feitas ainda mediçóes do ruído de tráfego. $\mathrm{O}$ microfone foi posicionado com tripé a, aproximadamente, 2,0 m e, posteriormente, a 0,15 m de distância da fachada. As mediçóes de pressão sonora com uso de ruído de tráfego foram feitas em 2 baterias, sendo o intervalo de tempo entre elas, basicamente, o necessário para reposicionar o sonômetro e ajustar esses medidores.

Na Figura 19, é exibido o gráfico do nível de pressão sonora medido por banda de frequência nas mediçóes que utilizaram ruído de tráfego como fonte sonora, a dois metros da fachada e a quinze centímetros dela.

As diferenças obtidas com os 2 posicionamentos do sonômetro são inferiores às obtidas nos ensaios anteriores, fato que pode ter sido suscitado pelas possíveis flutuaçóes do ruído de tráfego durante as mediçóes, visto que não foram realizadas simultaneamente, reforçando-se a necessidade de se realizar mediçôes simultâneas, e também pelo posicionamento do microfone a quinze centímetros, que impede a medição da reflexão máxima promovida pela superfície da fachada. Conforme observado por Olafsen (2012), acima de $1000 \mathrm{~Hz}$, há uma queda significativa na energia sonora, que pode não ser suficiente para realizaçáo de mediçóes de isolação sonora de fachadas de alto desempenho. 


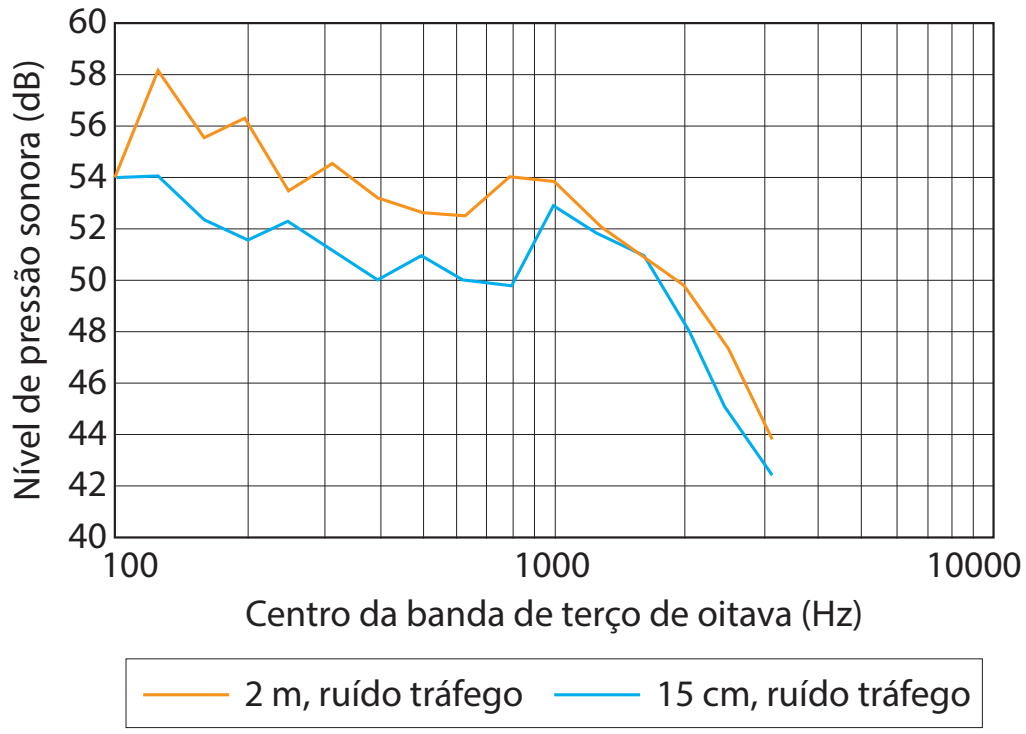

Figura 19. Nível de pressão sonora a dois metros da fachada e próximo a esse mesmo local.

A diferença de nível de pressão sonora equivalente, obtida utilizando a caixa acústica, foi de apenas $0,6 \mathrm{~dB}$, o que também se deve ao posicionamento do microfone, que estava próximo o suficiente, a ponto de receber apenas parcialmente a pressão sonora proveniente da reflexão da fachada. As diferenças de nível obtidas por faixa de frequência são mostradas nas Figuras 20 e 21.

Os dados obtidos demonstram, como era esperado, que o uso da caixa acústica supriu a deficiência de energia sonora a partir dos $1000 \mathrm{~Hz}$ e evidenciaram um comportamento de queda de nível de pressão sonora próximo à fachada, na regiấo entre 315 e $800 \mathrm{~Hz}$, decorrente de interferência destrutiva entre as ondas incidentes e refletidas pela fachada. 
Avaliação de Desempenho de Tecnologias Construtivas Inovadoras:

Conforto Ambiental, Durabilidade e Pós-Ocupação

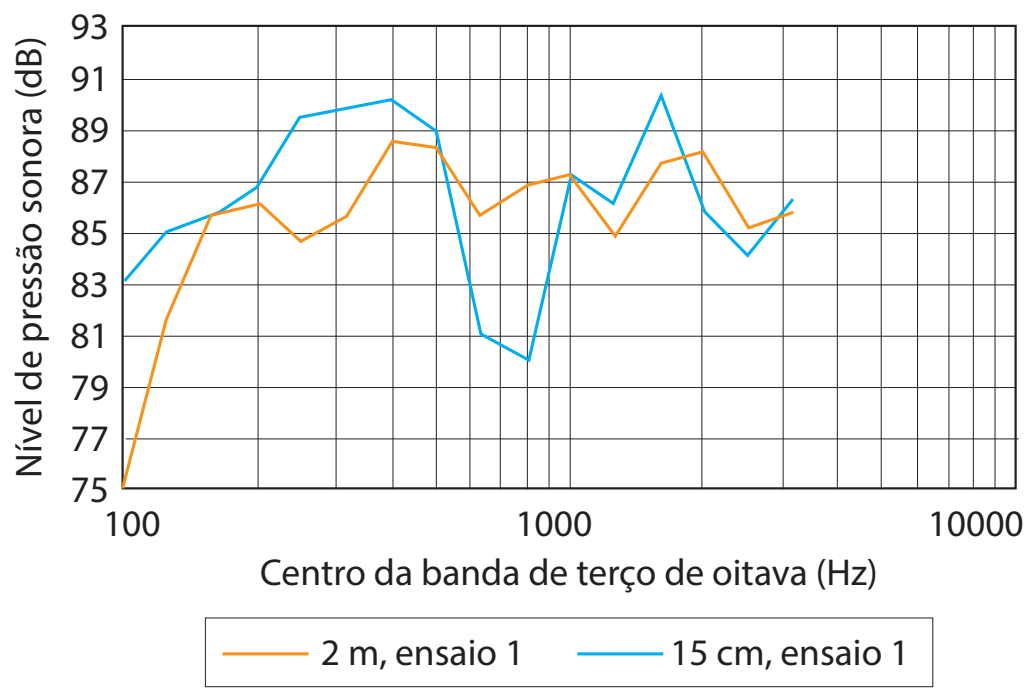

Figura 20. Nível de pressão sonora por banda de terço de oitava no primeiro ensaio.

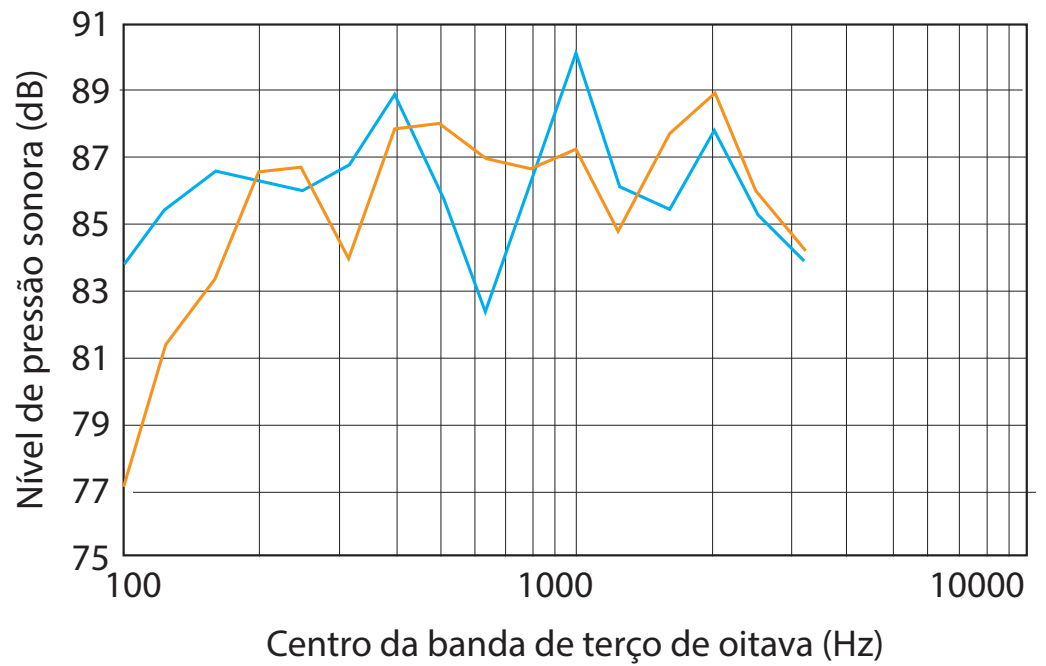

$2 \mathrm{~m}$, ensaio 2 $15 \mathrm{~cm}$, ensaio 2

Figura 21. Nível de pressão sonora por banda de terço de oitava no segundo ensaio. 


\section{Recomendações para Uso de Método de Medição de Isolação Sonora em Fachadas}

Tipicamente, as variaçóes nos níveis de pressão sonora equivalentes obtidas nos estudos realizados, considerando os efeitos de posicionamento de caixa, rugosidade de fachadas, nível de pressão sonora emitidos, uso de espuma protetora e presença de operador durante as mediçóes, foi inferior a $0,5 \mathrm{~dB}$. Contudo, houve variaçóes de até $1,6 \mathrm{~dB}$, o que sugere a necessidade de se considerar a possibilidade de haver diferenças dessa ordem de grandeza, quando se pretende utilizar um valor de nível de pressão sonora equivalente obtido junto à fachada como estimativa daquele que seria obtido a $2 \mathrm{~m}$ de distância. Por segurança, sugere-se adotar um valor de $2 \mathrm{~dB}$.

Nos casos em que a unidade analisada possua varanda e que isso facilite o posicionamento do microfone distante do SVVE, recomenda-se que seja utilizado o método global com uso de ruído de tráfego, conforme descrito na norma ISO 16283-3 (ISO, 2016). Este método envolve a fixação do microfone a um metro de distância da fachada, e as incertezas provenientes desse posicionamento e da possível presença de um operador, quando não for possível fixar o microfone, estâo devidamente asseguradas dentro da incerteza operacional proposta de $2 \mathrm{~dB}$.

Outra possibilidade é a incorporação direta desse fator de correção de nível de pressão sonora no cálculo da isolação, de forma a se subtrair o valor fixo de nível de pressão sonora equivalente ao valor obtido, através de mediçôes rentes à fachada, com o objetivo de calcular o parâmetro $\mathrm{D}_{2 \mathrm{~m}, \mathrm{n} \text { T,w }}$. O guia ASTM E966 propóe o uso dos fatores de correçáo de $2 \mathrm{~dB}$ nos casos em que são utilizados microfones próximos à fachada ou de $5 \mathrm{~dB}$ quando são utilizados microfones especiais embutidos na fachada (flush microphones). Isso, contudo, exigiria mais estudos antes de se propor uma normatização.

Além disso, ressalta-se a importância de utilizar três posiçôes de microfone na fachada, a fim de melhor caracterizar o ruído incidente, durante as mediçôes externas, ou cinco posiçôes se houver varandas, também conforme a exigência apresentada na norma ISO 16683-3 (ISO, 2016).

Vários dos artigos citados apontam a possibilidade de que caixas acústicas não sejam sempre as fontes sonoras mais adequadas para a realização 
de medições de isolação sonora de SVVE em campo. A própria norma ISO 16283-3 (ISO, 2016) indica que o método que utiliza o tráfego como fonte de ruído é o "preferido para estimar isolação sonora global de uma fachada", situação típica de grandes cidades, onde é comum a construção de edifícios altos. O mesmo documento assinala também a aplicação do método que emprega alto-falantes como uma alternativa ao anterior.

Usualmente, a utilização de caixas acústicas com ruído padronizado permite que as mediçôes efetuadas no ambiente externo e interno sejam feitas em momentos distintos. Contudo, ao se utilizar o ruído de tráfego que apresenta variaçóes significativas tanto no nível de ruído como na composição espectral ao longo do tempo, as medições no exterior e no interior da edificação devem ser realizadas simultaneamente, evitando, desta forma, a influência das oscilações naturais do tráfego na qualidade das mediçóes.

Sugere-se aqui que, para que o método possa ser utilizado de forma adequada, sejam analisados previamente os espectros sonoros produzidos pelo ruído de tráfego a ser utilizado nas medições, de forma a satisfazer não apenas aos critérios geométricos descritos na norma ISO 16683-3 (ISO, 2016), mas também a apresentar um nível total de pressão sonora superior a $70 \mathrm{~dB}$, medido na fachada, garantindo haver energia sonora suficiente para que seja avaliada a isolação sonora com razoável confiabilidade metrológica.

Destaca-se, contudo, que durante avaliaçóes de desempenho dentro do contexto do mercado brasileiro podem ser encontradas fachadas de edifícios próximas a outros prédios, de forma que o efeito de sucessivas reflexóes, as quais não são previstas na norma ISO (já que esta exige total visibilidade da linha de tráfego a partir da fachada em análise), se fazem presentes. O erro produzido por tal efeito, todavia, será ainda melhor analisado.

Com base nos estudos aqui descritos, verifica-se que é possível adotarse o método de elemento com uso de ruído de tráfego, descrito na norma ISO 16283-3 (ISO, 2016), tomando os cuidados acima discutidos para se realizar a estimativa do isolamento sonoro de fachadas em campo, complementando a norma NBR 15575-4. 


\section{Referências}

AMERICAN SOCIETY FOR TESTING AND MATERIALS - ASTM E966. Standard Guide for Field Measurements of Airborne Sound Insulation of Building Facades and Facade Elements. 10e1, 2011.

ASSOCIAÇÃO BRASILEIRA DE NORMAS TÉCNICAS - ABNT. NBR 10152: Níveis de ruído para conforto acústico - Procedimento. 1992.

ASSOCIAÇÃO BRASILEIRA DE NORMAS TÉCNICAS - ABNT. NBR 15575: Edificaçóes Habitacionais - Desempenho. Parte 4: Requisitos para os sistemas de vedaçôes verticais internas e externas - SVVIE. Quarta Edição, 2013.

HALL, F.L; PAPAKYRIAKOU, M.J.; QUIRT, J.D. Comparison of outdoor microphone locations for measuring sound insulation of building facades. Journal of Sound and Vibration, v. 92, n. 4, p. 559-567, 1984.

INTERNATIONAL ORGANIZATION FOR STANDARDIZATION - ISO 140: 1998. Acoustics - Measurement of sound insulation in buildings and of building elements - Part 5: Field Measurements of airborne sound insulation of façade elements and façades. Second Edition, 1998.

INTERNATIONAL ORGANIZATION FOR STANDARDIZATION - ISO 717-1: 2013. Acoustics - Rating of sound insulation in buildings and of building elements - Part 1: Airborne sound insulation. Third Edition, 2013.

INTERNATIONAL ORGANIZATION FOR STANDARDIZATION - ISO 162833: 2016. Acoustics - Field measurement of sound insulation in buildings and of building elements - Part 3: Façade Sound Insulation. First Edition, 2016.

LABORATÓRIO DE CONFORTO AMBIENTAL E SUSTENTABILIDADE DOS EDIFÍCIOS-CETAC-IPT. Certificado de Calibração No127 123-101. Item: Analisador de Nível Sonoro; Identificação: MNS-02, 2013.

MACHIMBARRENA, M.; MONTEIRO, C.R.A.; PEDERSOLI, S.; JOHANSSON, R.; SMITH, S. Uncertainty determination of in situ airborne sound insulation measurements. Applied Acoustics, v. 89, pp. 199-210, 2015.

OLAFSEN, S.; Measurements of facade sound insulation using a loudspeaker or railbound vehicles as sources. Joint Baltic-Nordic Acoustics Meeting, BNAM2012, 2012.

SÁNCHEZ BOTE, J.L.; PEDRERO GONZÁLEZ, A.; GÓMEZ ALFAGEME, J.J. Influence of loudspeaker directivity and measurement geometry on direct acoustic levels over façades for acoustic insulation tests with the International Standard ISO 140-5. Applied Acoustics, v. 73, pp. 440-453, 2012. 
